\title{
Modernitetens modsigelser Konfigurationskonflikter og samfundstænkning i Grundtvigs »Om Mennesket i Verden«
}

\author{
Af Henning Eichberg
}

En orm - en gud. Om mennesket $i$ verden. Ove Korsgaard (red.). Med bidrag af Niels Buur Hansen, Hans Hauge, Bosse Bergstedt, Uffe Jonas og Knud Bjarne Gjesing. Odense Universitetsforlag 1997.

I 1817 skrev Grundtvig et mærkeligt lille skrift, som kan betragtes som nøgle til forståelsen af hans filosofi og psykologi, men som står i et lidt usikkert forhold til hans senere samfundsmæssige engagement. Det har hidtil heller ikke spillet nogen særlig rolle i Grundtvigreceptionen. Hvad skal vi så med det i dag?

Det prøver antologien »En orm - en gud «, som Ove Korsgaard har udgivet på Odense Universitetsforlag, at give forskellige bud på. Bogen indeholder både originalteksten »Om Mennesket i Verden« og kommentarer fra litterære, kulturvidenskabelige og psykologiske indfaldsvinkler. Men hvordan kan man gribe opgaven an?

Enten kan man gå idéhistorisk-idéanalytisk til værks: Hvad ville Grundtvig sige? Det er overvejende på denne måde, at antologiens kommentarer spørger - i denne forstand i takt med Grundtvig-forskningens tradition - og svarene er velargumenterede, nuancerede og oplysende. Eller man kan anvende ideologikritikken: Hvor gik Grundtvig galt $\mathrm{i}$ byen, på grund af hvilke interesser (og hvor er vi klogere i dag)? Denne spørgemåde, som engang har været i højsædet, vil en og anden læser måske savne i bogen; og faktisk indeholder ideologikritikken ikke kun (alt for megen) bedreviden, men også en del kritiske muligheder.

Erkendelsesinteresse kan imidlertid også pege i en tredje retning, og dette skal være min egen tilgang i det følgende. »Om Mennesket i Verden« viser nemlig på en fængslende, undertiden gribende måde, hvordan et moderne menneske prøver at komme til klarhed over sit menneskesyn og placering i verden med modsigende sproglige, metaforiske og billedmæssige mønstre, som somme tider spænder ben for ham, så han snubler. Teksten tegner et levende billede af, hvordan ens egne ord danner konfigurationer, som bag ens ryg fortæller andre historier end dem, man selv har tænkt. 
Der må være en dybere logik i disse modsigelser, og dilemmaet kan godt have rod i konkrete samfundsmaessige modsætninger. Antologiens kommentarer er ikke særligt opmærksomme på denne side og trænger derfor til et supplement.

Den filosofiske brydning hos Grundtvig sker i begyndelsen af den modernitet, som også er vores - skønt den måske er under afvikling. Hvis Grundtvigs skrift har betydning i dag, så er det - efter min fornemmelse - ikke på grund af et system, som har holdt eller holder stik, men først og fremmest på grund af diskursens indre modsigelser. Hvor jeg kan genkende mine egne problemer her i senmoderniteten.

Hvordan kan vi altså nå frem til modsigelserne i denne tekst - som især Hans Hauge, men også andre blandt forfatterne, meget rammende beskriver som litterære, dramatiserende, ironiserende etc. slyngninger og labyrintiske søgebevægelser?

\section{Dualismen og dens uorden}

Grundtvig tænker som et moderne menneske gennemgående i hovedmodsætninger. Sine duale konstruktioner opbygger han gerne som dikotomiske, antagonistiske, nogle gange polemiske modsætningspar.

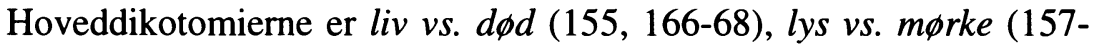
58) og sandhed vs. løgn (157-58, 160, 201).

Disse modsætningspar er ikke dialektisk konstruerede, der er ikke balance mellem tese og antitese, men de viser en klar stillingtagen for den ene side, enten - eller. Grundtvig står ikke for død, mørke og løgn, men for liv, lys og sandhed. Dermed placerer han sig i den kristne tradition, som i sin bibelortodokse, fundamentalistiske udgave beherskede Grundtvigs liv og forfatterskab på dette tidspunkt (og som han i senere år tog afstand fra): Gud vs. fanden (185) og det gode vs. det onde (199).

Men samtidig hersker der en flot uorden i andre af Grundtvigs dualismer:

Således er Grundtvig optaget af spørgsmålet, om mennesket er faldet, eller om det er oprejst (178-79,198). Fald vs. oprejsning - modsætningsparret viser snarere mod et paradoksalt forhold, som indeholder og vedkender sig modsigelsen. Paradokset har det i sig, at det generelt sætter dualismen ud af kraft og henviser til noget tredje. 
I forhold til sin egen stil og sprog sætter Grundtvig det lave vs. tankehøjden (163-64). At stå på en høj kan give en interessant udsigt, men går man ned, så bringer det andre fordele. Her vedkender han sig det spøgende, der kommer som en heks og har med latter og konflikt at gøre. Og faktisk skæmter Grundtvig og flakker ironiserende rundt $\mathrm{i}$ hele teksten, mens han filosoferende sidder og smøger sin morgenpibe med tøfler og nathue på. Den positive vurdering af det lave kontrasterer med Grundtvigs kristen-moderne positive vurdering af højden i øvrigt: Gud er i det høje og taler med »Røst fra Oven« (201). Og evolutionistisk set er »den høiere Orden« i naturen det positive (193). Hvor det lave og jævne i sprog og udtryk værdsættes, har vi derimod snarere med et socialt modsætningspar at gøre: Det folkelige prioriteres over for det elitære. Lyset kommer nedefra. (Ove Korsgaard har omhandlet det i bogen »Kampen om lyset «.) Grundtvigs vurdering af bevægelsen op/ned er altså yderst kontroversiel - ja, i grunden revolutionær; vi befinder os 30 år før 1848 .

Igen i en tredje metodisk retning peger det, når Grundtvig funderer over modsætningsparret legeme vs. ånd (178). Det beskriver et bådeog - og står i øvrigt i kontrast til den kristne kropsfjendtlighed. Polariteterne natur vs. historie (196) og tid vs. evighed (157-58) peger ligeledes mod en snarere dialektisk sammentænkning end en polemisk dikotomi.

Vender man herfra tilbage til dualiteten mellem liv og død, så bliver også dette modsætningspar langt mindre klart og entydigt, end man kunne have tænkt sig. Døden er nemlig ikke kun det modsatte af livet, men også selv en del af livsprocessen. Uden død er der intet liv. Spændingsforholdet ligger snarere inden for livet: død vs. kærlighed - og heller ikke dette kan forstås som et udelukkelsesforhold, men som to modstridende muligheder. På den ene side: Er en sten død - ligesom et lig er dødt? Og på den anden: $\cdot$ Hvis vi kalder stenen for død, så tilskriver vi dermed alligevel indirekte mineralet liv - og ånd - eller hvorfor ikke? Liv vs. død er ikke en naturgiven dualisme, den er snarere kulturel og samfundsmæssig: Hvis vi sætter den døde viden og den sorte skole over for skolen for livet, så er det en flot grundtvigsk polemik og meningsfuld i kulturkampen. Men det betyder ikke, at liv og død filosofisk set er bare antagonistiske. Og i den moderne lægevidenskab har netop kampen for livet og »mod døden« ført til den uhyggelige apparatfejl-model og dermed til en ekstrem form for »død viden«. Sådan set er døden livets sidste bevis. 
Den dualistiske konfiguration i diskursen, som ser så enkel og firkantet (tokantet) ud, producerer altså systematisk uorden - gennem en blanding af polaritet og polemik, af antagonisme og graduering, af dikotomier, udelukkelsesforhold og paradokser, gennem dialektiske, svævende eller i sig selv modsigelsesfulde billeder og vurderinger. Denne uordentliggørelse sker stik imod intentionen, både imod den kristne ordenstanke og mod den moderne binære rationalitet, som begge to hævder at beskrive virkeligheden i al klarhed.

\section{Trialektiske forhold}

Dualismens uorden eller uduelighed til at beskrive livet enten klart eller nuanceret lægger op til at afprøve en trialektisk strukturering. Og det er lige netop det, som Grundtvig fors $\emptyset$ ger gennem at postulere en trepolsmodel som disposition for filosofien: Menneskets position i verden er bestemt af et tredobbelt forhold - til legemet, til ånden og til menneskets selv (166-78). Mennesket er gjort af støv, har fået indblæst livsånde og er dermed blevet til en levende sjæl (175). Mennesket er konge (over legemet), tjener (af ånden) og statholder (178). Treklangen kan også beskrives med ordene: materie, ånd og sind (25).

Grundtvig skitserer også $\mathrm{i}$ andre sammenhænge trialektiske forhold. Han undersøger bl.a. menneskets tredobbelte forhold til tiden, rummet og sandheden (159). Der er også tre tidsaldre: de åndige syners tid, følelsens tid og begrebernes tid (199-200); de kaldes med andre ord hhv. mytologisk, teologisk og historisk tid (113) og sammenlignes med barndom, ungdom og manddom (113-17) eller også med Faderen, Sønnen og Helligånden (117-25); senere talte Grundtvig om ungdom, voksentid og alderdom med henvisning til nornerne Urd, Verdande og Skuld.

Det har givet anledning til at se trialektiske forhold mellem reduktionismen, holismen og Grundtvigs tretænkning (17-19), mellem materialisme, idealisme og det levende ord. På metodeplan kan man også sammenligne den fysisk-analytiske, induktive vej (at måle lig), den teologiske eller teoretiske deduktion (ud fra bogen) og den fænomenologiske vej (ud fra erfaring, sprogbilleder og introspektion).

De dualistiske mønstre hos Grundtvig og hans næsten krampagtige fors $\emptyset \mathrm{g}$ på at opretholde eller nyetablere dem er altså kun den ene 
side. Den anden er den kraft, Grundtvig lægger i at bryde dem, i at komme ud $i$ en diskurs om trefoldige forhold og spændinger. Sammenholder man disse tankebevægelser og hans permanente falden tilbage til dualistiske metaforer, så stiller spørgsmålet sig, om dette er en ren intellektuel anstrengelse - eller leg - eller om den har en »dybere«, en samfundsmæssig mening - og dermed måske en samfundsmæssig betydning netop for os.

Her kan vi referere til Grundtvigs egen intention: »Kun da nytter Vidskaben os, naar vi ikke attraa den for sin egen Skyld, men for at beskiæmme Tvivlen og styrke Troen i og omkring os ... At philosophere uden Tro er det samme som at ville se uden Øine « (162). Hvis man ser bort fra den kristne sprogbrug, som her udgør den indholdsmæssige overflade, så indeholder ordene et strukturelt budskab: Den filosofiske videnskabelighed skal ikke lade sig fange i den lærde akademisme med dens positivistiske tekstkritik, dens idéhistoriske indplaceringer og dens fortolkninger af fortolkninger af fortolkninger. Men det afgørende er: Hvad skal vi med det her i vores liv?

Kan vi bruge den originalitet, som Grundtvig selv har lagt i teksten, til at kvalificere originaliteten af vort eget projekt? Og hvad er det for et projekt?

At filosofere uden tro, uden lidenskab, uden egen holdning til livet er det samme som at ville se uden øjne - sådan kunne vi oversætte Grundtvig. Livet først, vidskab så. Eller lige ud: Hvad er det politiske i teksten?

Lad os altså spørge efter det samfundsmæssige i Grundtvigs skrift - og i hans dialektisk-trialektiske dilemma. Under dette spørgsmål er vi nødt til at vende tilbage til hans beskrivelse af det trialektiske spændingsforhold, som for ham udgør filosofiens kerne og kendetegner menneskets placering i verden.

\section{Legeme, ånd og sjael}

Hvad menneskets legeme angår, så har hånden en - også i bogstavelig forstand - fremragende betydning (168-69, 172-73, 192, 194-95). Den lægger op til beføling og følelse, til at fatte (det håndgribelige), til at be-gribe (begrebet), at begribe sig selv og sin egen skygge. En fugl i hånden er også for kundskabens skyld bedre end ti i luften (172). Mennesket kan ikke begribe noget større end sig selv (195). Håndre- 
laterede associationer som det at handle, håndtering og handlekraft danner kontrast til en vis romantisk kvietisme og stillesidden.

I takt med at Grundtvig tillægger hånden så stor betydning, tager han indirekte afstand fra distancesansen synet, fra fremhævelsen af $\varnothing$ jet, som ellers karakteriserer den moderne tænkning (171-72, 19091). Det sker på trods af Grundtvigs personlige mørkerædsel (Hauge 74) og hans begejstring for lys- og oplysningsmetaforikken. (Herfra kunne man tegne linier til indsigterne hos Denis Diderot om den blindes erkendelse, hos Goethe om farvelæren, hos den senere Ludwig Wittgenstein om hånden og visheden og hos Michel Foucault om panoptikonet).

Den vigtige og helt centrale ide er - som især Ove Korsgaard har understreget - at videns vej ikke går fra det fysisk-elementære til livets højere ordener, som positivismen i lang tid har postuleret. (Altså ikke »fra molekyle til bevægelse«, som det nye idrætsinstitut på Københavns Universitet beskriver sin erkendelsesvej). Men forståelsen går den omvendte vej: fra mennesket og livet »nedad « til materien. Grundtvig lægger op til en radikal antropologisering af naturvidenskaben.

Hvorvidt det er passende at diskutere denne vidensbevægelse som en hierarkisk ontologi, kan man derimod være i tvivl om. Begrebet hierarki med dets konstruktionsprincip op vs. ned er igen alt for dualistisk struktureret og desuden alt for snævert bundet til bestemte historisk-samfundsmæssige magtbilleder - den faraoniske pyramide, enevældens statsopbygning, den militære rangorden, den totalitære centralisme - hvis man vil beskrive de komplekse forhold mellem sten, plante, dyr, mennesket og »det større «. Der er altså god grund til - med Grundtvig - at kritisere den hierarkiske tænknings nedefraog-op, som fysikalismen, positivismen og funktionalismen står for; men hvis man bare vender den hierarkiske vej om til et oppefra-ogned, forbliver man for tæt bundet til éndimensionaliteten. At antropologisere naturvidenskaben og at se naturen ud fra livet er en helt anderledes radikal tilgang end pyramidetænkningen.

Ånden får i Grundtvigs skrift kun et kortere kapitel - måske fordi det netop på grund af vores videns bevægelsesmulighed »nedad«, fra mennesket over dyret og planten til mineralet, er så svært at sige noget »opad «. Ånden er nemlig noget, som er større end mennesket. Den åbenbarer sig i ord og sprog, i sang og poesi. Mennesket lever i »Samfund med den evige, levende Sandhed i Aanden«. 
Og så er der menneskets selv eller sjal som det tredje. Det beskriver et dobbelt, »statholderligt« forhold til selvstændigheden i verden og til samfundet med skaberen, den højere sfære.

Hvad er pointen i denne tredeling og i menneskets ejendommelige mellemplacering?

\section{Ånd og samfund}

Grundtvigs begreb om »samfundet « kan lede os ind på et spor, som fører ud af hans kristne univers - som for ham kun overgangsvis havde »fundamentalistisk « betydning og for det gudløse eller gudinderige menneske $\mathrm{i}$ vor tid snarere ingen betydning har. Sporet viser hen mod mere grundlæggende konfigurationale forhold. Aandigt Samfund mellem Menneske og Sandhed (177, 181-86) - det er ganske vist ikke det moderne samfundsbegreb, men det peger fra det enkelte menneske hen mod noget større, som ligger i »sam-et«, menneske og menneske imellem. Ord og sprog (og sang og poesi) er samfunds- og samspilsmæssige, de forudsætter menneskets møde og fællesskab med andre mennesker.

Og dette samfundsmæssige fællesskab kan mennesket - som Grundtvig ganske rammende siger - ikke »begribe« med hånden, det er »større«. Det større kulturelle fællesskab kan heller ikke afledes ud fra det enkelte menneske, ligesom mennesket ikke kan afledes ud fra molekylerne. Ud fra vor rent individuelle hånd-begrebslighed kan vi ikke engang udtømmende »fatte« en fællesdans til musik, endsige et idræts-landsstævne; men vi kan med åndens kraft begive os »opad « i »Samfundet« - og derfra og »nedad « prøve at begribe os selv.

Det samfundsmæssige ved ånden bliver yderligere understreget, hvor Grundtvig går i detaljerne med, »hvad jeg forstaaer ved Aand «. Ånden er en kraft, som hos mennesket har tre virkninger - vilje, samvittighed og tro (180 ff). Viljen giver næppe mening, hvis ikke den retter sig fra det enkelte menneske mod andre. Samvittigheden vidner sprogligt direkte om dette »sam-«, om relationen menneske og menneske imellem. Og troen betegner i vort sprog ikke kun »tro på Gud « men også et troskabsforhold til vennen, til ens gruppe eller fællesskab, til folket eller nationen. De åndelige forhold i Grundtvigs beskrivelse betegner altså allesammen sociale forhold og deres psykologiske grundlag. 
I det følgende nævner Grundtvig ved siden af vilje, samvittighed og tro endnu andre "Aande-Livets Spor «, som igen bekræfter det interaktive og samfundsbestemte ved åndsbegrebet. Ordet er menneskets og folkets »eneste Opreisnings-Middel« (186). Historien som »Spor af Aanden« udtrykker sig i poesi, kunst og videnskabelighed, som de enkelte folkefærd udvikler hver for sig $(188,196)$. Og så er der karligheden: „Vi kan vel ikke her begribe, hvorfor der skulde, sandselig, være mere end eet Menneske til, begribe hvorfor det ikke var godt at Mennesket blev alene, men føle kan vi det i Kiærlighed « (189).

Ordet, historien, kærligheden: Åndslivet kan altså - på en god ateistisk måde - forstås som samfundsliv, som en højere form af subjektivitet. Samfundet i denne forstand - kultur, social identitet, folk er ikke kun en ophobning af enkeltmennesker, ikke kun summen af individerne, men en ny kvalitet på et andet niveau, ligesom mennesket repræsenterer et nyt niveau over for dyret og planten et nyt niveau over for mineralet.

Trialektikken i »Om Mennesket i Verden« siger altså i vort sprog: Mennesket har sit sted mellem grundstoffernes liv og det samfundsmaessige liv. Mellem krop og kultur.

\section{Tilbage til dualismen?}

Det netop sagte kan give anledning til en kritisk drøftelse af antologiens titel: »En orm - en gud«. Bogtitlen stammer ikke fra Grundtvigs egne ord i hans filosofiske artikel, men fra et vers af 1700-tallets engelske præst og forfatter Edward Young, som Grundtvig citerer som motto. Hvis man vælger det som overskrift, så bliver konfigurationen ført tilbage til det dualistiske - som Grundtvig netop prøvede at overvinde. Problemet gentager sig, hvor en af kommentarerne taler om tredelingen i den moderne psykologi, men illustrerer dette med en strikte dualistisk opregning: subjekt vs. objekt, det ubevidste vs. det bevidste, Mig'et vs. Jeg'et etc. (Niels Buur Hansen 50). Vendt til det positive viser dette, hvor utroligt vanskeligt Grundtvigs projekt var, og hvor tungt den gamle modernitet og dens dualistiske fiksering belaster vore frig $\varnothing$ relsesfors $\varnothing \mathrm{g}$ den dag $\mathrm{i}$ dag.

Desuden reducerer bogtitlen sin genstand - livet, samfundet - til et enkeltvæsen (»en orm ...«). Den trækker dermed opmærksomheden 
væk fra det interaktive, samspilsmæssige, som er et kernepunkt i Grundtvigs tekst ligesom i enhver form af socialt orienteret filosoferen. Titlens formulering minder snarere om firsernes New-Agebølge med dens kosmologiseren og individualiseren af samfundsmæssige spørgsmål. Overfor dette er der grund til at huske 68 'ernes protosocialistiske Grundtvig: Det kosmologiske og teologiske kan samfundsmæssigg $\varnothing \mathrm{res}$, og mytologien kan godt være revolutionær ...

Hermed skal den betydning ikke underkendes, som New-Age-bølgen historisk set har haft for den kritiske tænknings udvikling. Hvor 1968 'ernes sprog var løbet ind i en ekstrem tingsliggørelse og teoribeton, der opblødte New-Age - både sproget og opmærksomheden, gjorde dem flydende og vitaliserede dem på ny. Eventyr, drømme og myter blev genopdaget ligesom $\emptyset$ stlige og indianske filosofier, og det blev muligt at udtrykke følelser. Men netop derfor er det vigtigt at være opmærksom på de veje, på hvilke den vesterlandske kategoribeton - højre vs. venstre hjernehalvdel, subjekt vs. objekt, det fysikalske og det planetariske uden samfund - igen sniger sig ind gennem bagdøren. Netop her ligger betydningen af Grundtvigs filosofiske brydninger, som vidner om lignende erfaringer.

Grundtvig skal altså ikke tages til indtægt som forløber for noget, der senere er blevet realiseret, opdaget eller opfundet - hverken for 1968 eller for New-Age. Men med Grundtvig fremstår et menneske, som havde et problem, der siger os noget - og som bearbejdede problemet radikalt, dvs. tilbundsgående. Han filosoferede på troens grund - men netop derfor med den (erkendte) risiko, at han kom til at beskadige sin egen tros grundlag.

\section{Folket som det tredje}

Det er imidlertid ikke nok i generelle vendinger at konstatere betydningen af den samfundsmæssige dimension i Grundtvigs tekst. Livshistorisk peger teksten fremad mod den betydning, som det folkelige fik for den senere Grundtvig. Men hvilken mere konkret samfundsmæssighed taler vi om - og hvilket samfund udtrykte Grundtvig i den industrielle modernitets startfase, han befandt sig i? Findes der en sammenhæng mellem diskursens og samfundets indre modsigelser?

Den moderne tænkning fra Grundtvig op til vore dage er præget af en enerådende dualisme: idealisme vs. materialisme hhv. økonomis- 
me, ånd vs. materie, subjektivitet vs. objektivitet. Eller mere politisk sagt: feudalisme vs. kapitalisme, præmodernitet vs. modernitet, enevælde vs. demokrati, restauration vs. revolution. Det var altid vanskeligt at placere Grundtvig i disse binære mønstre.

På samfundsplan svarer de fleste af disse todelinger ret nøje til den fremherskende dualisme mellem staten og markedet. Her står ideelle værdier over for materielle interesser. Orden gennem administration, præsteskab og militær står i et spændingsforhold til produktion, distribution og forbrug af produkter og tjenesteydelser. Den politiske handling er konfronteret med den kommercielle handel. Kritisk kan man også kalde det: formynderi vs. egoisme. Eller i den demokratiske revolutions positive programbegreber: lighed vs. frihed.

De to samfundsmæssige sfærer hhv. handlingsmåder havde og har imidlertid noget tredje ved siden af sig - eller som grundlag - det civile samfund. Dette tredje er i samfundsteorien sjældent eller aldrig blevet medtænkt. (Vigtige henvisninger findes hos Alexis de Tocqueville, Max Weber, Antonio Gramsci og Michel Maffesoli.) Mens der eksisterer mangfoldige friheds- og lighedsteorier, mangler vi i høj grad teorier om broder- hhv. søsterskabet. Det er dette, som den senere Grundtvig lagde op til med ordene folket, folkelighed og det folkelige liv. Der eksisterer biblioteker fulde af stats- og markedsteorier, men en folketeori skal vi lede længe efter.

Set ud fra dette perspektiv ligger Grundtvigs »Om Mennesket i Verden « ikke, som det ved overfladisk betragtning kunne se ud til, så langt fra hans (senere) folkeligheds-besættelse. Tværtimod, den formulerer folkebegrebets filosofiske basis. Dette sker imidlertid i meget abstrakte vendinger - med folk snarere som mulighedsform eller som søgekategori.

Dermed er altså ikke alt sagt - tværtimod, alt står åbent. Hvad betyder det, når det kommer til stykket, at folk og ånd (det levende ord, poesi, kærlighed) hænger sammen? Hvad betyder det, at det civile samfund har sin psykologiske basis i menneskets vilje, samvittighed og tro - eller skulle vi i mellemtiden finde frem til en mere passende psykologi? Hvordan hænger i det folkelige fællesskab kropslighed og spiritualitet sammen? Eller hvordan forholder shamanens, åndemanerens, healerens - og Grundtvigs spiritualitet sig til den åndelighed, som præsten og magten står for ...? 


\section{Dialogisk materialisme}

Herfra kan vi vende tilbage til det erkendelsesteoretiske og søge hjælp hos Martin Buber og hans filosofi om jeg'et, det'et og du'et hhv. det dialogiske princip.

Legemet kan vi nemlig tale om som noget fysisk, som en genstand, et objekt - et »det«. Legemet lægger altså op til et det-forhold.

Menneskets forhold til sig selv findes derimod der, hvor mennesket siger »jeg « til sig selv. Selv'et eller selvbevidstheden er knyttet til et jeg-forhold.

Den dualistiske behandling af jeg-forholdet (subjektivitet) vs. detforholdet (objektivitet) er i det moderne samfund lige så enerådende som dualismen mellem staten og markedet.

Men der er noget tredje, ånden, som Grundtvig kalder et »kiærligt Samfund med Sandhed « (186). Dette betegner noget grundlæggende dialogisk, et du-forhold. Det svarer til, hvad Martin Buber har kaldt "det evige du « - altså Bubers udspil til et ateistisk gudsbegreb. Dette »du« er grundlag for vi-forholdet, som den senere Grundtvig var så optaget af og kaldte folkelighed.

Prøver man imidlertid en stringent triangulering af det-, jeg- og du-forholdene, så støder man hos Grundtvig på noget, som kan virke som roderi - og måske er det. Det mest dialogiske i Grundtvigs fremstilling er nemlig ikke Ånden, men menneskets forhold til sig selv, altså jeg-forholdet. Grundtvig beskriver menneskets selv næsten udelukkende som en balancegang, som en dialogisk forholden sig til de andre to, til legemet og ånden. Det »statholderlige « forhold, som karakteriserer menneskets selv, er i Grundtvigs fremstilling en »Forening «. Det kan forstås og uddybes med Martin Buber: Der er intet selv uden du. Du'et har altså en ekspansiv tendens: fra det evige du (det åndelige, det samfundsmæssige) til menneskets selv.

Hvis dette er mere end bare roderi og mere end en ufærdig søgen hos Grundtvig, så kan det åbne øjnene for en intenderet ubalance, som har en dybere mening. Det dialogiske, du'et, er basis for det he$l e$, ikke kun for menneskets forhold til selv'et (du-jeg) og til ånden (det evige du), men også for forholdet til legemet. Gennem Grundtvigs hele beskrivelse af det legemlige går der en undertone af indføling (med hånden), som sætter det objektiverende syn $\mathrm{i}$ anden række, en tone af kærlig og dialogisk henvendelse og »Tilbøjelighed $\ll$. 
Det understreger, hvor betydningsfuldt det er, at håndfølelsen prioriteres over synet. Thi dette implicerer en styrkelse af du'et over for det'et. Hånden har nemlig en kropslig partner, som den rører ved, mens synet ikke har; synet har rummet, som det breder sig ud over. Det er hånd-kropsligheden, der giver Grundtvigs filosofi en speciel »varme « og samtidig en markant ikke-idealistisk, kropslig-materialistisk grundtone - på trods af dens kristne billedsprog.

Denne kropsrelaterede materialisme har desuden undertoner, som vi i dag ikke kan forstå anderledes end som økologiske. Mennesket er broder eller søster ikke kun for sine lige, men også for dyret og planten og stenen.

Og så er den grundtvigske du-materialisme et modtræk imod den erkendelsesteoretiske individualisme, som netop for tiden vender tilbage som et pseudo-sociologisk postulat om, at nu er vi for alvor faldet ud af alle eksisterende overordnede bindinger - familie, kirke, nation, klasse - for at realisere os som enkeltmennesker på vore egne, selvvalgte og samfundsløse præmisser. Det er en illusion! - råber Grundtvig - ligesom Norbert Elias i vor tid har opbygget hele sin sociologi på tanken om, at individ og samfund netop ikke kan adskilles. Samfundet - menneskets samspil med legemet som med ånden optræder ikke uden for mennesket, men i menneskets egen krop og identitet.

\section{Den ufardige socialisme}

At tænke det dialogiske (samfundet, du'et, kærligheden) og identiteten (vi'et), det kropsligt-materielle (hånden) og det civilsamfundsmæssige (folket) i sammenhæng - dermed er vi slet ikke færdige, og vi kan næppe se os bekræftet i noget som helst system. Men her begynder udfordringerne først. Udfordringer, som vi imidlertid godt har lov til - netop i opposition til den for tiden herskende individualiseringsdiskurs - at kalde socialisme. Hvis vi altså under socialisme forstår noget, som ikke har været der endnu.

Det er i det ufærdige, at mulighederne ligger.

Grundtvig blev klogere i sit livs forløb. F.eks. karakteriserede han i 1817 Odin og Frigga som »Natur-Kræfter« og tilskrev dem sammen med Ulysses-myten det onde. »Den har Fanden skabt« (185). I 1832 blev de derimod til historisk-poetiske sindbilleder, altså til billeder fra 
menneskets psyke. Også vi er blevet klogere - ikke mindst gennem den samfundsmæssige Grundtvig, som er blevet opdaget $\mathrm{i}$ årene efter 1968.

Men i opdagelsen ligger også, at det menneske, som Grundtvig fremstiller som »Mennesket i Verden«, er en mærkelig blanding af mandligt og kønsløst væsen, som åbenbart eksisterer ved siden af »Piger«, som er nævnt enkelte steder; dette skæve kønsforhold har Grundtvig senere gennem sin fabuleren om Guds datter rettet lidt op på. Desuden er menneskets »kongedømme« over legemet og over naturen - som et magtforhold - langt fra at være en rammende beskrivelse. Den passer alt for godt til den psykiatriske sygeliggørelse på den ene side og den (u)økologiske udryddelsestendens på den anden, som karakteriserer industrikulturen.

Vi kan også blive klogere, ligesom Grundtvig blev det. At man kan blive klogere, betyder imidlertid ikke, at vi nu overskuer terrænet, ikke engang at vi overskuer det bedre. Thi i klogskabens historie indgår også glemsel og tab. Det indgår også i det billede, som Grundtvig har tegnet af tankehøjen, hvor »man fristes til at løfte sig paa Tæerne, for deels at see lidt videre, deels lidt højere over andre Hoveder paa Marken « - og så (på den anden side) fordelen ved »at gaa ned, thi der ... skielner man meget bedre mellem Skin og Virkelighed...«. I det lave kan den materialistiske hånd (»du her«) hjælpe med at kontrollere synets idealbilleder (»det der«).

Vi står altså med skriftet »Om Mennesket i Verden« med et fors $\emptyset \mathrm{g}$ på ud fra en filosofisk psykologi at grundlægge en kritisk samfundsteori. Med kosmologisk-teologiske billeder og begreber bliver et antropologisk projekt udviklet, som til syvende og sidst vedrører menneskets socialitet. En socialitet, som er større og smukkere, end det enkelte menneske kan begribe det med hånden - men som måske udtrykkes nok så godt med hånden. Det er et udkast til, hvad senere blev historisk virksomt som Grundtvigs folkelige anarkisme, med andelsbevægelsen som følge. Og det er en opfordring til os om at blive lige så originale $\mathrm{i}$ vor opfattelse af og omgang med verden. Lever vi op til det? 


\section{Yderligere litteratur:}

Buber, Martin 1923: Ich und Du. - På dansk: Jeg og du. København, Reitzel 1992.

Diderot, Denis 1749: Lettre sur les aveugles à l'usage de ceux qui voient. I: Oeuvres complètes. Paris 1974 ff., bd.4. - Se også: Anne Elisabeth Sejten 1995: The Enlightenment and Views of Nature. Diderot's Deconstruction of the Concept of Nature. I: Mette Bryld et al. (eds.): Bodyscapes. Odense, Odense Universitetsforlag 1995, s. 55-69.

Goethe, Johann Wolfgang von 1798/1823: Farbenlehre. I: Werke. Hamburg, Wegner 1960, bd.14/2. Og i: Werke. Weimar, Böhlau 1890, bd.II/2. - Se også: Margret Bothe 1986: Goethe und Newton: Kritik an der neuzeitlichen Wissenschaft. I: Leviathan 14:1, s. 37-60.

Eichberg, Henning 1990: Krop, legeme - og hvad ellers. Overvejelser over den tredje krop. I: Centring 9:25, s. 24-40.

Foucault, Michel 1975: Surveiller et punir. La naissance de la prison. Paris. - På dansk: Overvågning og straf. Det moderne faengselsvaesens historie. København, Rhodos 1977.

Gramsci, Antonio 1929-35: Quaderni del carcere. - På dansk: Fangselsoptegnelser. Bd.1-2, København, Museum Tusculanum 1991. - Se også: Sabine Kebir 1991: Gramsci's Zivilgesellschaft. Hamburg, VSA.

Grundtvig, N.F.S. 1832: Nordens Mythologi eller Sindbilled-Sprog, historisk-poetisk udviklet og oplyst. 3.opl. 1870, nyudg. København, Samleren 1983.

Korsgaard, Ove 1997: Kampen om lyset. Dansk voksenoplysning gennem 500 år. København, Gyldendal.

Maffesoli, Michel 1996: The Time of the Tribes. The Decline of Individualism in Mass Society. London, Sage. 
Weber, Max 1922: Wirtschaft und Gesellschaft. Nyudg. Tübingen, Mohr 1972.

Wittgenstein, Ludwig 1969: Über Gewissheit. Oxford. - Se også Gunter Gebauer 1984: Hand und Gewissheit. I: Dietmar Kamper/ Christoph Wulf (Hrsg.): Das Schwinden der Sinne. Frankfurt/Main, Suhrkamp s. 234-260. 